\title{
Improvement of Napier Grass Silage Nutritive Value by Using Inoculant and Crude Enzymes from Trichoderma reesei and Its Effect on in Vitro Rumen Fermentation
}

\author{
D. J. Nurjana ${ }^{a}$, S. Suharti ${ }^{b}, \&$ Suryahadi ${ }^{b, *}$ \\ aStudy Program of Nutrition and Feed Science, Faculty of Animal Science, Graduate School, \\ Bogor Agricultural University \\ ${ }^{\mathrm{b}}$ Department of Nutrition and Feed Technology, Faculty of Animal Science, Bogor Agricultural University \\ Jalan Agatis, Kampus IPB Darmaga Bogor 16680, Indonesia \\ (Received 09-11-2015; Reviewed 04-12-2015; Accepted 15-01-2016)
}

\begin{abstract}
This research was aimed to evaluate the effect of inoculant and crude enzyme of Trichoderma reesei on fermentation quality and rumen digestibility of napier grass silage. This research consisted of two stages. The first stage was fermentation quality using a completely randomized design with three treatments and six replications. The second stage was rumen fermentability using a randomized block design with three treatments and six replications. The treatments of both stages were: $\mathrm{T} 0=$ control of napier grass silage (Hi-fer+), T1= control $+T$. reesei inoculant at the level of $2.13 \times 10^{7} \mathrm{cfu} /$ $\mathrm{kg}$, and $\mathrm{T} 2=$ control + crude enzyme from $T$. reese $i$ at the level of $11.4 \mathrm{unit} / \mathrm{kg}$. Napier grass silage were kept at room temperature and opened $21 \mathrm{~d}$ after fermentation. The result of the first stage experiment showed that $\mathrm{T} 2$ decreased $(\mathrm{P}<0.01)$ dry matter, organic matter, crude fiber, and neutral detergent fiber $(\mathrm{NDF})$ and also increased $(\mathrm{P}<0.05)$ crude protein, total digestible nutrient $(\mathrm{TDN}), \mathrm{pH}$, acetic acid, and propionic acid of napier grass silage while $T 1$ decreased $(P<0.01)$ NDF and increased $(P<0.05)$ propionic acid. The result of the second stage experiment showed that there were no significant differences in rumen $\mathrm{pH}$, in vitro dry matter and organic matter digestibility, total VFA, proportion of VFA, ratio of acetic to propionic acids, and also $\mathrm{NH}_{3}$. It is concluded that the addition of crude enzyme from $T$. reesei could improve fermentation quality of napier grass silage with decreasing NDF and increasing TDN but did not affect rumen fermentability.
\end{abstract}

Key words: napier grass, silage, Trichoderma reesei, enzyme, in vitro

\section{ABSTRAK}

Penelitian ini bertujuan untuk mengevaluasi pengaruh inokulan dan enzim kasar asal Trichoderma reesei pada kualitas produk silase rumput gajah dan kualitas fermentabilitas rumen. Penelitian terdiri atas dua tahap. Tahap pertama merupakan pengujian kualitas produk silase rumput gajah. Percobaan ini menggunakan rancangan acak lengkap dengan tiga perlakuan dan enam ulangan. Tahap kedua bertujuan untuk menguji fermentabilitas rumen yang menggunakan rancangan acak kelompok dengan tiga perlakuan dan enam ulangan. Perlakuan untuk kedua tahap penelitian adalah $\mathrm{T} 0=$ kontrol, $\mathrm{T} 1=\mathrm{kontrol}+$ inokulan $T$. reesei dosis $2,13 \times 10^{7} \mathrm{cfu} / \mathrm{kg}$, dan $\mathrm{T} 2=\mathrm{kontrol}+$ crude enzyme dari T. reesei dosis 11,4 unit $/ \mathrm{kg}$. Silase rumput gajah disimpan pada suhu ruang dan dibuka 21 hari setelah fermentasi. Hasil tahap pertama menunjukkan bahwa T2 menurunkan $(P<0.01)$ bahan kering, bahan organik, serat kasar, dan NDF, serta meningkatkan $(P<0,05)$ protein kasar, TDN, $\mathrm{pH}$, asam asetat, dan asam propionat dari silase rumput gajah; sedangkan T1 menurunkan $(P<0,01)$ NDF dan meningkatkan $(P<0,05)$ asam propionat. Hasil percobaan tahap kedua menunjukkan bahwa $\mathrm{pH}$ rumen, kecernaan bahan kering dan bahan organik in vitro, total VFA, proporsi VFA, rasio asetat/ propionate, dan $\mathrm{NH}_{3}$ sama antarperlakuan. Kesimpulan dari penelitian ini, penambahan enzim kasar asal T. reesei dapat meningkatkan kualitas produk silase rumput gajah dengan menurunkan NDF dan meningkatkan TDN, tetapi belum berpengaruh terhadap fermentabilitas rumen.

Kata kunci: rumput gajah, silase, Trichoderma reesei, enzim, in vitro

*Corresponding author:

E-mail: ipbsurya56@yahoo.co.id 


\section{INTRODUCTION}

The qualified and sustainable forages availability is needed in the ruminant farm. Seasonal changes affect the availability of forages. The availability of forage is abundant in rainy season, while shortage of forage is often occurred in dry season. The shortage of quality forage has become the limiting factor for development of ruminant farm resulting in the decreased ruminant production. To overcome the shortage of forage during dry season, the development of forage preservation technology such as fermented forage/silage called $\mathrm{Hi}-$ fert is needed.

Fermented forage/silage (Hi-fer+) is a forage preservation technology through ensiling process added with special fermentation additive and packed in airtight plastic bags. Ensiling is forage preservation process under anaerobic fermentation condition (McDonald et al., 1991). Ensiling reduce $\mathrm{pH}$ of fermented product through homofermentation process of major water soluble carbohydrate (WSC) to lactic acid by lactic acid bacteria (LAB), thereby harmful microorganism can be inhibited and nutrient content can be preserved (Sun et al., 2009). Special fermentation additive component consists of growth promoter for microbes, palatability enhancer, minerals from organic acids and antioxidant. Technology of fermented forage/silage and special fermentation are developed by Center for Tropical Animal Studies (CENTRAS), LPPM, Bogor Agricultural University. The preservation process of fermented forage/silage is occurred due to LAB using the available WSC produce lactic acid that causes a rapid decline in fermented forage/silage $\mathrm{pH}$ that eventually preserves nutrient and prevents the growth of undesirable microorganism.

Ensiling of tropical forages are difficult because these forages have high fiber content, low dry matter (DM) content, low concentration of WSC, and low crude protein (CP) content (Avellaneda et al., 2009; Bureenok et al., 2012). Thus, the digestibility of tropical forage is quite low. Fibrolytic enzymes, molasses, glucose were often used as additives to improve fermentation quality of silage (Dean et al., 2005; Li et al., 2014). To improve fermentation quality and digestibility of fermented forage, it can be done by using Trichoderma reesei activity.

T. reesei is known to produce enough cellulose and hemicellulose (Juhász et al., 2005). The potential of $T$. reesei can be useful to degrade cell wall plant thereby improving the digestibility of fermented forage. T. reesei can grow at $\mathrm{pH} 4$ to 7 (Bailey et al., 1993) that is expected to work in fermentation process of fermented forage. Addition of lactic acid bacteria to forage at ensiling promotes homofermentation of major water soluble carbohydrate (WSC) to lactic acid, thereby causes a rapid decline of silage $\mathrm{pH}$ and increase silage quality (Amanullah et al., 2014; Ridwan et al., 2015). While the addition of $T$. reesei inoculant in fermented forage was expected to grow in the earlier fermentation that still had available oxygen so that the $T$. reesei could use substrate of plant to produce cellulase and could accelerate anaerobic condition. When the fermentation condition was anaerobic, the cellulase could be used to enhance degradation of fiber plant and increase WCS content as substrates for lactic acid bacteria to produce more lactic acid and to preserve the nutrients.

Utilization of enzyme activity from $T$. reesei can be done through crude enzyme extraction. Crude enzyme can be used to improve nutritive quality of silage. Hidayat et al., (2005) reported that addition of crude enzyme derived from Trichoderma viride improved dry matter digestibility and organic matter digestibility of rice straw silage. Production of crude enzyme requires substrate as medium growth. T. reesei cultivated with cellulose and lignocellulose substrates as carbon source produces enzymes such as cellulase, amylase, hemicellulose, ligninase, peptidase and proteinase (Adav et al., 2012; Saloheimo \& Pakula, 2012). Rice straw contains cellulose, hemicellulose and lignin that can be used as substrate for production of crude enzyme. Addition of crude enzyme derived from $T$. reesei was expected to produce more substrates for LAB at the early stage of fermentation by enhancing fiber degradation. During silage fermentation, added cellulase degrades cellulose to sugar and the LAB uses it to produce lactic acid (Sun et al., 2012). This process result in rapid increase in lactic acid and a drop in $\mathrm{pH}$, which inhibits activities of nonlactic acid bacteria and plant enzymes for proteolysis (Sun et al., 2012; Li et al., 2014).

The use of $T$. reesei inoculant and crude enzyme derived from $T$. reesei in process of making napier grass silage was expected to improve fermentation quality of napier grass silage. This study was aimed to evaluate the effect of $T$. reesei inoculant and crude enzyme derived from $T$. reesei on fermentation quality of napier grass silage, dry matter and organic matter digestibility and rumen fermentation product determined by in vitro.

\section{MATERIALS AND METHODS}

\section{Trichoderma reesei Culture}

The strain for inoculant and crude enzyme production was T. reesei QM6a. T. reesei QM6a was collected from IPB Culture Collection (IPBCC), Bogor, Indonesia. Stock cultures of $T$. reesei were maintained on potato dextrose agar (PDA) slants in test tubes at room temperature $\left(28-30^{\circ} \mathrm{C}\right)$ for $7 \mathrm{~d}$, and stored at $4^{\circ} \mathrm{C}$ when spores were formed as described by Prabavathy et al. (2006).

\section{Crude Enzyme from Trichoderma reesei Production}

Crude enzyme from $T$. reesei was produced according to the method of Anwar et al. (2010). Rice straw was sun-dried for $4 \mathrm{~d}$, then cut and milled. Rice straw sample $(20 \mathrm{~g})$ was soaked in $80 \mathrm{~mL}$ of $2 \% \mathrm{NaOH}$ aqueous solution and kept at $120^{\circ} \mathrm{C}$ for $30 \mathrm{~min}$, then washed with tap water to neutral $\mathrm{pH}$, then dried at $60^{\circ} \mathrm{C}$.

Around $5 \mathrm{~g}$ of rice straw powder was added in $250 \mathrm{~mL}$ Erlenmeyer flask containing $25 \mathrm{~mL}$ of liquid medium, then sterilized at $121^{\circ} \mathrm{C}$ for $15 \mathrm{~min}$. Liquid medium was used for crude enzyme containing $1.0 \mathrm{~g}$ yeast extract, $1.5 \mathrm{~g}$ bacteriological peptone, $1.4 \mathrm{~g}\left(\mathrm{NH}_{4}\right)_{2} \mathrm{SO}_{4^{\prime}}$ $2.0 \mathrm{~g} \mathrm{KH}_{2} \mathrm{PO}_{4}, 0.005 \mathrm{~g} \mathrm{FeSO}_{4} .7 \mathrm{H}_{2} \mathrm{O}, 5 \mathrm{~mL}$ of $1 \% \mathrm{CMC}$ in each liter of $0.1 \mathrm{M}$ acetic buffer with $\mathrm{pH}$ 5.0. This me- 
dium was inoculated with $T$. reesei spore suspension of $1.8 \times 10^{8} \mathrm{cfu} / \mathrm{mL}$ and incubated for $6 \mathrm{~d}$. After incubating, culture broth was added $100 \mathrm{~mL}$ of $1 \%$ Tween 80 in 0.1 $\mathrm{M}$ acetic buffer with $\mathrm{pH} 5.5$ and stirred at $175 \mathrm{rpm}$ for $135 \mathrm{~min}$. After stirring, culture broth was centrifuged at $8000 \mathrm{rpm}$ for $10 \mathrm{~min}$ at $4^{\circ} \mathrm{C}$ and the supernatant was analyzed for filter paper activity (FPA). The FPA to measure enzyme activity was determined according to Ghose (1987) method.

\section{Fermented Forage/Silage (Hi-fer+) Preparation}

Forage used in this study was Napier grass (Pennisetum purpureum). Napier grass was cultivated in experimental field at Faculty of Animal Science, IPB. The grass was harvested at $60 \mathrm{~d}$ after planting and air-dried for a night. The harvested grass was chopped into small pieces about $5 \mathrm{~cm}$ length. The chopped grasses were added $2 \%$ additive fermentation (CENTRAS LPPM IPB) and 7\% molasses, and then packed in low density polyethylene plastic $(270 \mathrm{~mm} \times 50 \mathrm{~mm} \times 0.07 \mathrm{~mm}$ ) with 2 layers. Inoculant and crude enzyme were mixed with additive fermentation before being added in forage. The dosage of $T$. reesei inoculant was $2.13 \times 10^{7} \mathrm{cfu} / \mathrm{kg}$ fresh weights. The dosage of crude enzyme addition or supplementation to napier grass silage was $11.4 \mathrm{IU} /$ $\mathrm{kg}$ fresh weights based on previous study (Hidayat et al., 2005). The amount of forage in each plastic was $3 \mathrm{~kg}$. Six plastics per treatment were prepared. Napier grass silage were kept at room temperature and opened after 21 days of fermentation.

\section{Chemical Analysis}

Napier grass before fermentation and napier grass silage sample were dried at $60^{\circ} \mathrm{C}$ for $48 \mathrm{~h}$ and milled for chemical analysis. Dry matter (DM), organic matter $(\mathrm{OM})$, crude protein $(\mathrm{CP})$, crude fiber $(\mathrm{CF})$ and ether extracts (EE) were determined according to the method of AOAC (2005). Total digestible nutrient (TDN) content was calculated according to the formula of Hartadi et al. (1980). Neutral detergent fiber (NDF) and acid detergent fiber (ADF) were determined by Van Soest et al. (1991).

Around $20 \mathrm{~g}$ of napier grass silage samples were blended with $200 \mathrm{ml}$ sterilized water. Napier grass silage juice was used to analyze $\mathrm{pH}$, acetic acid, propionic acid, butyric acid, lactic acid, and $\mathrm{NH}_{3}$ (ammonia). The $\mathrm{pH}$ value was measured with $\mathrm{pH}$ meter (Hanna HI98107). Lactic acid was analyzed by the titration method AOAC (2005). Acetic acid, propionic acid, and butyric acid were analyzed by using gas chromatography (GC 8A, Shimadzu Crop., Kyoto, Japan, Capillary column type containing $10 \% \mathrm{SP}-1200,1 \% \mathrm{H}_{3} \mathrm{PO}_{4}$ on $80 / 100$ Cromosorb WAW and nitrogen as gas carrier). The concentration of $\mathrm{NH}_{3}$ was analyzed by using Conway microdiffusion method.

\section{In Vitro Study}

The samples of napier grass silage of day 21 were analyzed in vitro according to Tilley \& Terry (1963) method. The rumen fluid was collected $2 \mathrm{~h}$ after the morning feeding from three fistulated Ongole Crossbred beef cattle's in Indonesia Institute of Sciences, Cibinong, Bogor, which was cared for according to Ethical Approval from Animal Care and Use Committee (ACUC) 01-2013b IPB. The in vitro study was evaluated in six in vitro runs, each in vitro run used rumen fluid from a fistulated Ongole crossbred beef cattle. Rumen samples were transferred into a pre-warmed thermos flask for transport to the laboratory. These fluids were filtered through two layers of cheesecloth under a continuous stream of $\mathrm{CO}_{2}$. Air-dried napier grass silage samples (500 mg) were put into $100 \mathrm{~mL}$ fermentation tube and warmed at $39^{\circ} \mathrm{C}$ before being added $40 \mathrm{~mL}$ McDougall buffer and $10 \mathrm{~mL}$ rumen fluid under continuous stream of $\mathrm{CO}_{2}$. The fermentation tubes were closed with rubber stopper and incubated in a $39^{\circ} \mathrm{C}$ shaker water bath. The fermentation fluid of $4 \mathrm{~h}$ incubation was collected to determine $\mathrm{pH}$, volatile fatty acid (VFA) and $\mathrm{NH}_{3}$ while fermentation fluid of $48 \mathrm{~h}$ incubation was collected to determine in vitro dry matter digestibility (IVDMD) and in vitro organic matter digestibility (IVOMD).

The $\mathrm{pH}$ of rumen was measured with $\mathrm{pH}$ meter. Total VFA concentration and molar proportion of VFA were analyzed by using gas chromatography (GC 8A, Shimadzu Crop., Kyoto, Japan). The concentration of $\mathrm{NH}_{3}$ was analyzed by using Conway micro diffusion method. IVDMD and IVOMD were determined by using Tilley \& Terry (1963) method.

\section{Statistical Analysis}

The chemical and fermentation product analysis was conducted in a completely randomized design with three treatments and six replications. The in vitro study was conducted in a randomized block design with three treatments and six replications. Different rumen fluid for each incubation run of in vitro served as block in the statistical model. The treatments were as follows: (1) T0 (Napier grass silage (Hi-fer+) without additives as control), (2) T1 (napier grass silage with addition of inoculant $T$. reesei at $2.13 \times 10^{7} \mathrm{cfu} / \mathrm{kg}$ fresh weights) and (3) T2 (napier grass silage with addition of crude enzyme from $T$. reesei at 11.4 unit $/ \mathrm{kg}$ fresh weights). Data were analyzed by using the Analysis of Variance (ANOVA) and the differences between means were compared by using Duncan's Multiple Range Test.

\section{RESULTS AND DISCUSSION}

\section{Activity of Crude Enzyme from Trichoderma reesei}

Enzyme activity (FP-ase) of crude enzyme derived from T. reesei was $0.50 \mathrm{IU} / \mathrm{mL}$ that was tested in $30^{\circ} \mathrm{C}$ and $\mathrm{pH}$ 5. The result was lower than that was reported by Fang et al. (2010) that FP-ase activity of enzyme from T. reesei was $2.48 \mathrm{IU} / \mathrm{mL}$. The Fp-ase activity reported by Fang et al. (2010) was tested in $50^{\circ} \mathrm{C}$ and $\mathrm{pH} 4.8$. This was caused by the different of $T$. reesei strain and medium substrates, in which Fang et al. (2010) used T. reesei strain RUT-C30 and corn stover as substrates. Jun et al. (2013) reported that FP-ase activity of enzyme from 
T. reesei strain RUT-C30 with xylose as substrates was $0.62 \mathrm{IU} / \mathrm{mL}$. This result indicated that production of enzyme from $T$. reesei depend on strain, source of carbon, temperature, and $\mathrm{pH}$.

\section{Chemical Composition of Napier Grass Silage}

The crude enzyme derived from $T$. reesei (T2) treatments significantly decreased $(\mathrm{P}<0.01)$ the contents of $\mathrm{DM}, \mathrm{OM}$ and $\mathrm{CF}$ of napier grass silage as compared with control (T0) and T. reesei inoculant (T1) (Table 1). The decreased DM and OM contents in napier grass silage treated with crude enzyme was probably due to the increased degradation process of fiber into fermentable carbohydrate in the crude enzyme treatment. Therefore, the LAB used starches and sugars to produce lactic acid and volatile fermentation products. The degradation process of starches and sugars to lactic acid or VFA caused a decrease in DM of napier grass silage. Similar finding was reported by Dehghani et al. (2012) that some fibrolytic enzyme treatments decreased DM of maize stover silages. The CF content of napier grass silage treated with crude enzyme was lower than other treatments, indicating that crude enzyme was more efficient in degrading plant cell wall than $T$. reesei inoculant only. McDonald et al. (1991) stated that cell wall degrading enzymes should degrade cell wall component to simpler molecules, so that providing more substrate for lactic acid bacteria.

The crude enzyme treatment significantly increased $(\mathrm{P}<0.05) \mathrm{CP}$ content of napier grass silage. The increased $\mathrm{CP}$ content was due to the decrease in OM, especially carbohydrate, thus the proportion of protein increased. This result indicated that crude enzyme addition was able to promote LAB growth and to prevent proteolysis process from microbes and plant enzymes, so that encourage reduced protein degradation in ensiling process of napier grass silage. Similar finding was reported by $\mathrm{Li}$ et al. (2014) that addition of cellulase additive increased $\mathrm{CP}$ content of king grass silage.

The DM, OM, CP, CF, and TDN contents of napier grass silage treated with $T$. reesei inoculant did not differ significantly than the control $(P>0.05)$. There were no significant differences in EE contents of napier grass silage among treatments $(\mathrm{P}>0.05)$. Similar finding was reported by Li et al. (2014) that addition of cellulase did not affect EE content of king grass silages.

Crude enzyme treatment of napier grass silage increased $(\mathrm{P}<0.05)$ TDN content compared with control and inoculant treatments. This effect could probably due to a higher CP content and a lower CF content in crude enzyme treatment. The $T$. reesei inoculant and crude enzyme treatments significantly decreased $(\mathrm{P}<0.05)$ NDF contents of napier grass silage than control. The NDF content of napier grass silage treated with crude enzyme was lower than other treatments, indicating crude enzyme treatment was more effective than $T$. reesei inoculant treatment to degrade NDF. Similar finding was reported by Xing et al. (2009) and Li et al. (2014) that cellulase additive decreased NDF content of silages. Addition of enzymes to silage should degrade fiber partially to water soluble carbohydrate (WSC) for used by LAB (Eun \& Beauchemin, 2007). The ADF contents of fermented silages did not differ $(\mathrm{P}>0.05)$ among treatments. This result indicated that ADF fraction have not been effectively degraded by inoculant and crude enzyme.

\section{Fermentation Characteristic of Napier Grass Silage}

The $\mathrm{pH}$ value of napier grass silage was influenced by additive treatments. Napier grass silage treated with T. reesei inoculant had higher $(\mathrm{P}<0.05) \mathrm{pH}$ value than other treatments (Table 2). The $\mathrm{pH}$ value of all fermented forages was below 4, which was an indicator of wellpreserved napier grass silage. According to McDonald et al. (1991), pH value for silage should be below 4.5 to preserve the silage. It indicated all napier grass silage met these criteria as well-preserved quality. The addition of crude enzyme slightly increased $\mathrm{pH}$ of napier grass silage. Xing et al. (2009) reported that addition of fibrolytic enzyme did not alter $\mathrm{pH}$ value in sorghum straw silages. High concentration of acetic acid, propionic acid and $\mathrm{NH}_{3}$ in napier grass silage treated with crude enzyme caused slightly increasing $\mathrm{pH}$ value. The addition of $T$. reesei inoculant may be led to heterofermentative bacteria growth resulting in higher $\mathrm{pH}$ value, lower lactic acid and higher VFA product contents. Arriola et

Table 1. Nutrient compositions of napier grass and napier grass silage after $21 \mathrm{~d}$ ensiled

\begin{tabular}{lcccccc}
\hline \multirow{2}{*}{ Chemical compositions } & \multirow{2}{*}{ Napier grass } & \multicolumn{3}{c}{ Treatments } & \multirow{2}{*}{ SEM } & \multirow{2}{*}{ P-value } \\
\cline { 3 - 5 } & & T0 & T1 & T2 & & 0.286 \\
Dry matter (DM) (\%) & 17.24 & $21.71^{\mathrm{B}}$ & $22.74^{\mathrm{B}}$ & $20.19^{\mathrm{A}}$ & 0.008 \\
Organic matter (\% DM) & 88.61 & $87.01^{\mathrm{B}}$ & $86.97^{\mathrm{B}}$ & $85.59^{\mathrm{A}}$ & 0.153 & 0.002 \\
Crude protein (\% DM) & 6.51 & $6.76^{\mathrm{a}}$ & $6.84^{\mathrm{a}}$ & $7.40^{\mathrm{b}}$ & 0.096 & 0.032 \\
Ether extract (\% DM) & 1.35 & 1.70 & 2.08 & 2.26 & 0.114 & 0.163 \\
Crude fiber (\% DM) & 29.51 & $28.95^{\mathrm{B}}$ & $28.71^{\mathrm{B}}$ & $25.65^{\mathrm{A}}$ & 0.467 & 0.001 \\
Total digestible nutrient (\% DM) & 49.63 & $50.76^{\mathrm{a}}$ & $51.79^{\mathrm{a}}$ & $54.61^{\mathrm{b}}$ & 0.534 & 0.027 \\
Neutral detergent fiber (\% DM) & 72.19 & $67.76^{\mathrm{C}}$ & $66.13^{\mathrm{B}}$ & $62.96^{\mathrm{A}}$ & 0.304 & $<0.001$ \\
Acid detergent fiber (\% DM) & 46.48 & 44.13 & 44.38 & 42.83 & 0.397 & 0.263 \\
\hline
\end{tabular}

Note: $\mathrm{T} 0=$ control; $\mathrm{T} 1=\mathrm{control}+\mathrm{T}$. reesei at $2.13 \times 10^{7} \mathrm{cfu} / \mathrm{kg}$ fresh weight; $\mathrm{T} 2=$ control + crude enzyme from $T$. reesei at $11.4 \mathrm{unit} / \mathrm{kg}$ fresh weight. SEM= standard error of means. Means in the same row with different small superscripts differ significantly $(\mathrm{P}<0.05)$; means in the same row with different capital superscripts differ significantly $(\mathrm{P}<0.01)$. 
al. (2011) reported that heterolactic bacteria fermentation had higher $\mathrm{pH}$ value, lower lactic acid concentration and higher acetic and propionic acid concentrations.

Lactic acid content did not differ significantly $(\mathrm{P}>0.05)$ among treatments. This might due to addition of $T$. reesei inoculant and crude enzyme derived from $T$. reesei did not improve $\mathrm{LAB}$ propagation at the fermentation time. Similar finding was reported by Dean et al. (2005) that addition of fibrolytic enzyme did not increase lactic acid concentration in bermudagrass silages. However, lactic acid concentration of napier grass silage treated with crude enzyme was slightly greater than control. The addition of crude enzyme improved NDF degradation to supply enough substrates for LAB growth, thereby slightly increased lactic acid concentration.

Acetic acid content of napier grass silage was influenced by additive treatments. Napier grass silage containing T. reesei inoculant had higher $(\mathrm{P}<0.05)$ acetic acid content than control. Huisden et al. (2009) and Bureenok et al. (2012) reported that the higher acetic acid concentration in silage was caused by the heterofermentative LAB growth. This result indicated that addition of $T$. reesei inoculant made the fermentation was dominated by heterofermentative bacteria and resulted in increasing acetic acid.

The inoculant and crude enzyme treatments significantly increased $(\mathrm{P}<0.05)$ propionic acid of napier grass silage than control. This result might due to fermentation of napier grass silage treated with inoculant and crude enzyme was dominated by hetero-fermentative LAB and probably promoted propionic acid bacteria. Similar finding was reported by Dehghani et al. (2012) that several fibrolytic enzymes increased propionic acid concentration in lucerne and maize stover silages. The concentration of acetic acid and propionic acid were high enough, that can be used to increase aerobic stability of napier grass silage. Sufficient concentrations of acetic acid and propionic acid increased aerobic stability of silages (Xing et al., 2009; Chen et al., 2014).

There was no significant difference $(\mathrm{P}>0.05)$ in butyric acid concentration of napier grass silage among treatments. Similar finding was reported by Dean et al. (2005) that several fibrolytic enzymes did not affect bu-

Table 2. Characteristics of napier grass silage after $21 \mathrm{~d}$ fermentations

\begin{tabular}{lccccc}
\hline \multirow{2}{*}{$\begin{array}{l}\text { Fermentation } \\
\text { characteristics }\end{array}$} & \multicolumn{3}{c}{ Treatments } & \multirow{2}{*}{ SEM } & P-value \\
\cline { 2 - 4 } & $3.53^{\mathrm{a}}$ & $3.62^{\mathrm{b}}$ & $3.57^{\mathrm{ab}}$ & 0.011 & 0.029 \\
$\mathrm{pH}$ & 57.95 & 52.69 & 69.79 & 3.224 & 0.119 \\
Lactic acid $(\mathrm{g} / \mathrm{kg} \mathrm{DM})$ & $7.87^{\mathrm{a}}$ & $21.12^{\mathrm{b}}$ & $16.05^{\mathrm{ab}}$ & 1.634 & 0.015 \\
Acetic acid $(\mathrm{g} / \mathrm{kg} \mathrm{DM})$ & $0.98^{\mathrm{a}}$ & $4.46^{\mathrm{b}}$ & $3.19^{\mathrm{b}}$ & 0.413 & 0.012 \\
Propionic acid $(\mathrm{g} / \mathrm{kg} \mathrm{DM})$ & 0.80 & 1.61 & 1.85 & 0.200 & 0.135 \\
Butyric acid $(\mathrm{g} / \mathrm{kg} \mathrm{DM})$ & 0.83 & 0.95 & 1.09 & 0.042 & 0.070 \\
$\mathrm{NH}_{3}(\mathrm{~g} / \mathrm{kg} \mathrm{DM})$ & & & & & \\
\hline
\end{tabular}

Note: $\mathrm{T} 0=$ control; $\mathrm{T} 1=\mathrm{control}+\mathrm{T}$. reese $i$ at $2.13 \times 10^{7} \mathrm{cfu} / \mathrm{kg}$ fresh weight; $\mathrm{T} 2=$ control + crude enzyme from $T$. reesei at 11.4 unit $/ \mathrm{kg}$ fresh weight. DM= dry matter; SEM= standard error of means. Means in the same row with different small superscripts differ significantly $(\mathrm{P}<0.05)$. tyric acid concentration in bermudagrass silages. Butyric acid concentrations of all napier grass silage were low indicating well-preserved napier grass silage. According to McDonald et al. (1991), silages containing more than $10 \%$ butyric acid are poorly preserved. The $\mathrm{NH}_{3}$ contents of all treatments were similar $(\mathrm{P}>0.05)$. This result indicated that addition of $T$. reesei inoculant and crude enzyme did not affect proteolysis activity in napier grass silage. Similar finding was reported by Xing et al. (2009) that $\mathrm{NH}_{3}-\mathrm{N}$ contents of control and fibrolytic enzyme treatment were similar in sorghum straw silages. $\mathrm{NH}_{3}$ contents of all treatments were low indicating good quality of napier grass silage. According to Xing et al. (2009) that low $\mathrm{NH}_{3}-\mathrm{N}$ content $(<25 \mathrm{~g} / \mathrm{kg} \mathrm{DM})$ showed a good silage.

\section{In Vitro Digestibility and Rumen Fermentation of Napier Grass Silage}

The mean $\mathrm{pH}$ of rumen fluid (6.90-6.93) was similar in all treatments (Table 3). According to Krause \& Oetzel (2006), normal rumen $\mathrm{pH}$ was 5.5-7.0. This result indicated that addition of control and treated of napier grass silage still maintained rumen condition suitable for feed fermentation process. The IVDMD and IVOMD contents did not show significant difference among different treatments. The decrease in CF and NDF contents of napier grass silage treated with crude enzyme did not cause the napier grass silage more easily degraded by rumen microbes, so that had similar IVDMD and IVOMD contents. Dehghani et al. (2012) reported that although addition of fibrolytic enzyme decreased NDF content but OMD of alfalfa silages was not affected by enzyme and even several enzymes treatment decreased OMD of maize stover silages. Different result was reported by Xing et al. (2009) that addition of complex enzyme (cellulase and hemicellulase) increased DMD of sorghum straw silages. The different responses may be due to different types of forage and enzyme. Thus, the addition of $T$. reesei inoculant and crude enzyme derived

Table 3. In vitro digestibility and rumen fermentation characteristics of napier grass silage

\begin{tabular}{|c|c|c|c|c|c|}
\hline \multirow{2}{*}{ Variables } & \multicolumn{3}{|c|}{ Treatments } & \multirow{2}{*}{ SEM } & \multirow{2}{*}{$\mathrm{P}$-value } \\
\hline & T0 & $\mathrm{T} 1$ & $\mathrm{~T} 2$ & & \\
\hline $\mathrm{pH}$ & 6.90 & 6.93 & 6.92 & 0.013 & 0.590 \\
\hline IVDMD (\%) & 51.15 & 51.81 & 50.85 & 0.587 & 0.798 \\
\hline IVOMD (\%) & 49.16 & 50.61 & 48.89 & 0.676 & 0.558 \\
\hline Total VFA (mM) & 54.51 & 50.35 & 46.75 & 3.904 & 0.727 \\
\hline Acetic acid (\% VFA) & 51.04 & 50.38 & 49.82 & 0.507 & 0.631 \\
\hline $\begin{array}{l}\text { Propionic acid } \\
(\% \text { VFA) }\end{array}$ & 32.88 & 33.07 & 33.45 & 0.487 & 0.889 \\
\hline Butyric acid (\% VFA) & 16.09 & 16.54 & 16.73 & 0.289 & 0.656 \\
\hline Ratio A/P & 1.57 & 1.58 & 1.54 & 0.031 & 0.891 \\
\hline $\mathrm{NH}_{3}(\mathrm{mg} / \mathrm{dl})$ & 10.26 & 11.21 & 9.58 & 0.442 & 0.358 \\
\hline
\end{tabular}

Note: $\mathrm{T} 0=$ control; $\mathrm{T} 1=\mathrm{control}+\mathrm{T}$. reese $i$ at $2.13 \times 10^{7} \mathrm{cfu} / \mathrm{kg}$ fresh weight; $\mathrm{T} 2=$ control + crude enzyme from $T$. reesei at 11.4 unit $/ \mathrm{kg}$ fresh weight. IVDMD= in vitro dry matter digestibility; IVOMD = in vitro organic matter digestibility; $\mathrm{VFA}=$ volatile fatty acid; Ratio $\mathrm{A} / \mathrm{P}=$ ratio acetic to propionic; $\mathrm{SEM}=$ standard error of means; $\mathrm{DM}=\mathrm{dry}$ matter. 
from $T$. reesei did not improve nutritive value of napier grass silage that was seen from IVDMD and IVOMD contents.

Total VFA production and molar proportion of VFA in rumen fluid did not differ significantly among treatments. The similar total VFA concentration was due to the addition of additives in napier grass silage did not stimulate rumen microbes' growth. The mean total VFA concentration (46.75-54.51 mM) was too lower than optimum concentration according to McDonald et al. (2011) i.e., 70 to $150 \mathrm{mM}$. The total VFA found in this study was slightly higher than total VFA of napier grass (48.54 mM) reported by Okoruwa \& Igene (2014). The different responses might be due to the low digestible carbohydrate and protein contents in napier grass silage resulting in differences microbial populations, thereby decreasing total VFA concentration. Suharti et al. (2011) reported that production of total VFA increased when the level of concentrate in ration increased. Molar proportion of acetic acid, propionic acid and butyric acid in the rumen fluid was not affected by treatments. All treatments showed lower ratio of acetic acid to propionic acid (1.54-1.57). The lower ratio of acetic acid to propionic acid was beneficial to animal production. Propionic acid is a main precursor to gluconeogenesis process in ruminant, which converted to glucose in liver; thereby glucose can be used by animal for production and reproduction (McDonald et al., 2011).

The rumen $\mathrm{NH}_{3}$ content $(9.58-11.21 \mathrm{mg} / \mathrm{dL})$ did not show significant difference among different treatments. The similar rumen $\mathrm{NH}_{3}$ indicated that treatments of napier grass silage provided similar efficient use of ammonia. This might due to addition of $T$. reesei inoculant and crude enzyme in napier grass silage had not improved fermentability of napier grass silage so that there was no change in the activity of rumen microbes leading to $\mathrm{NH}_{3}$ formation. In rumen, ammonia is used by rumen microbes as nitrogen source for microbial protein synthesis (McDonald et al., 2011). The mean rumen $\mathrm{NH}_{3}$ that was in optimum concentration according to McDonald et al. (2011) was 85 to $300 \mathrm{mg} / \mathrm{L}$. Syahrir et al. (2009) stated that the lower $\mathrm{NH}_{3}$ concentration indicated several reasons that are well-fermentation process thus utilization of ammonia occurred, the diet had CP that difficult to be degraded or the diet had low CP content. The low CP of napier grass silage in this study probably caused low concentration of rumen $\mathrm{NH}_{3}$ formed.

\section{CONCLUSION}

All treatments produced well-preserved napier grass silage with low $\mathrm{pH}$, high lactic acid and low butyric acid contents. The addition of $T$. reesei inoculant and crude enzymes derived from $T$. reesei increased acetic acid and propionic acid contents. The addition of crude enzymes derived from $T$. reesei improved fermentation quality of napier grass silage with increasing TDN, $\mathrm{CP}$, and decreasing NDF content of napier grass silage. Based on in vitro evaluation, the addition of T. reesei inoculant and crude enzymes did not cause negative effect on rumen fermentability of napier grass silages.

\section{ACKNOWLEDGEMENT}

This experiment was supported by funds from BPP-DN scholarship and CENTRAS LPPM IPB.

\section{REFERENCES}

Adav, S. S., L. T. Chao, \& S. K. Sze. 2012. Quantitative secretomic analysis of Trichoderma reesei strains reveals enzymatic composition for lignocellulosic biomass degradation. Mol. Cell. Proteomics 11: M111.012419-M111.012419.

Amanullah, S. M., D. H. Kim, H. J. Lee, Y. H. Joo, S. B. Kim, \& S. C. Kim. 2014. Effects of microbial additives on chemical composition and fermentation characteristics of barley silage. Asian-Australasian J. Anim. Sci. 27: 511-517.

Anwar, N., A. Widjaja, \& S. Winardi. 2010. Peningkatan unjuk kerja hidrolisis enzimatik jerami padi menggunakan campuran selulase kasar dari Trichoderma reesei dan Aspergillus niger. Makara Sci. Ser. 14: 113-116.

AOAC. 2005. Official Methods of Analysis of AOAC International, Association of Official Analysis Chemists International. Association of Official Analytical Chemists, Arlington.

Arriola, K. G., S. C. Kim, \& A. T. Adesogan. 2011. Effect of applying inoculants with heterolactic or homolactic and heterolactic bacteria on the fermentation and quality of corn silage. J. Dairy Sci. 94: 1511-1516. http://dx.doi.org/10.3168/ jds.2010-3807

Avellaneda, J. H., J. M. Pinos-Rodríguez, S. S. González, R. Bárcena, A. Hernández, M. Cobos, D. Hernández, \& O. Montañez. 2009. Effects of exogenous fibrolytic enzymes on ruminal fermentation and digestion of Guinea grass hay. Anim. Feed Sci. Technol. 149: 70-77. http://dx.doi. org/10.1016/j.anifeedsci.2008.05.003

Bailey, M., J. Buchert, \& L. Viikari. 1993. Effect of pH on production of xylanase by Trichoderma reesei on xylan- and cellulose-based media. Appl. Microbiol. Biotechnol. 40: 224-229. http://dx.doi.org/10.1007/BF00170371

Bureenok, S., C. Yuangklang, K. Vasupen, J. T. Schonewille, \& Y. Kawamoto. 2012. The effects of additives in napier grass silages on chemical composition, feed intake, nutrient digestibility and rumen fermentation. Asian-Australas. J. Anim. Sci. 25: 1248-1254.

Chen, L., G. Guo, X. Yuan, M. Shimojo, C. Yu, \& T. Shao. 2014 Effect of applying molasses and propionic acid on fermentation quality and aerobic stability of total mixed ration silage prepared with whole-plant corn in Tibet. AsianAustralasian J. Anim. Sci. 27: 349-356.

Dean, D. B., A. T. Adesogan, N. Krueger, \& R. C. Littell. 2005. Effect of fibrolytic enzymes on the fermentation characteristics, aerobic stability, and digestibility of bermudagrass silage. J Dairy Sci 88: 994-1003. http://dx.doi.org/10.3168/ jds.S0022-0302(05)72767-3

Dehghani, M. R., M. R. Weisbjerg, T. Hvelplund, \& N. B. Kristensen. 2012. Effect of enzyme addition to forage at ensiling on silage chemical composition and NDF degradation characteristics. Livest. Sci. 150: 51-58. http://dx.doi. org/10.1016/j.livsci.2012.07.031

Eun, J. S. \& K. A. Beauchemin. 2007. Enhancing in vitro degradation of alfalfa hay and corn silage using feed enzymes. J. Dairy Sci. 90: 2839-2851. http://dx.doi.org/10.3168/ jds.2006-820

Fang, H., C. Zhao, \& X. Y. Song. 2010. Optimization of enzymatic hydrolysis of steam-exploded corn stover by two approaches: Response surface methodology or using cellulase from mixed cultures of Trichoderma reesei RUTC30 and Aspergillus niger NL02. Bioresour. Technol. 101: 4111-4119. http://dx.doi.org/10.1016/j.biortech.2010.01.078 
Ghose, T. K. 1987. Measurement of cellulase activities. Pure Appl. Chem. 59: 257-268. http://dx.doi.org/10.1351/ pac198759020257

Hartadi, H., S. Reksohadiprodjo, S. Lebdosukodjo, \& A. D. Tillman. 1980. Tabel-Tabel dari Komposisi Makanan Ternak untuk Indonesia. Gadja Mada Univ Press, Yogyakarta.

Hidayat R, S. Wulandari, K. G. Wiryawan, \& Suryahadi. 2005. Production and utilization of cellulase from Trichoderma viride. Biotropia 25: 50-59.

Huisden, C. M., A. T. Adesogan, S. C. Kim, \& T. Ososanya. 2009. Effect of applying molasses or inoculants containing homofermentative or heterofermentative bacteria at two rates on the fermentation and aerobic stability of corn silage. J. Dairy Sci. 92: 690-697. http://dx.doi.org/10.3168/ jds.2008-1546

Juhász, T., Z. Szengyel, K. Réczey, M. Siika-Aho, \& L. Viikari. 2005. Characterization of cellulases and hemicellulases produced by Trichoderma reesei on various carbon sources. Process Biochem. 40: 3519-3525. http://dx.doi. org/10.1016/j.procbio.2005.03.057

Jun, H., H. Guangye, \& C. Daiwen. 2013. Insights into enzyme secretion by filamentous fungi: Comparative proteome analysis of Trichoderma reesei grown on different carbon sources. J. Proteomics 89: 191-201. http://dx.doi. org/10.1016/j.jprot.2013.06.014

Krause, K. M. \& G. R. Oetzel. 2006. Understanding and preventing subacute ruminal acidosis in dairy herds: A review. Anim. Feed Sci. Technol. 126: 215-236. http://dx.doi. org/10.1016/j.anifeedsci.2005.08.004

Li, M., X. Zi, H. Zhou, G. Hou, \& Y. Cai. 2014. Effects of sucrose, glucose, molasses and cellulase on fermentation quality and in vitro gas production of king grass silage. Anim. Feed Sci. Technol. 197: 206-212. http://dx.doi.org/10.1016/j. anifeedsci.2014.06.016

McDonald, P., R. A. Edwards, J. F. D. Greenhalgh, C. A. Morgan, L. A. Sinclair, \& R. G. Wilkinson. 2011. Animal nutrition, Animal nutrition. Pearson, Harlow.

McDonald, P., A. Henderson, \& S. Heron. 1991. The Biochemistry of Silage, Chalcombe Publications, Marlow. Chalcombe Publications, Marlow.

Okoruwa, M. I. \& F. U. Igene. 2014. Comparison of fermentation kinetics (in vitro) of napier grass and fruit peels for ruminants: the pattern of organic matter degradability, volatile fatty acids concentration, estimated methane and microbial biomass production. IOSR J. Agric. Vet. Sci. 7: 21-28. http://dx.doi.org/10.9790/2380-07132128
Prabavathy, V. R., N. Mathivanan, E. Sagadevan, K. Murugesan, \& D. Lalithakumari. 2006. Intra-strain protoplast fusion enhances carboxymethyl cellulase activity in Trichoderma reesei. Enzyme Microb. Technol. 38: 719-723. http:// dx.doi.org/10.1016/j.enzmictec.2005.11.022

Ridwan, R., I. Rusmana, Y. Widyastuti, K. G. Wiryawan, B. Prasetya, M. Sakamoto, \& M. Ohkuma. 2015. Fermentation characteristics and microbial diversity of tropical grasslegumes silages. Asian-Australas. J. Anim. Sci. 28: 511-518.

Saloheimo, M. \& T. M. Pakula. 2012. The cargo and the transport system: Secreted proteins and protein secretion in Trichoderma reesei (Hypocrea jecorina). Microbiology 158: 46-57. http://dx.doi.org/10.1099/mic.0.053132-0

Suharti, S., D. A. Astuti, E. Wina, \& T. Toharmat. 2011. Rumen microbial population in the in vitro fermentation of different ratios of forage and concentrate in the presence of whole lerak (Sapindus rarak) fruit extract. Asian-Australas. J. Anim. Sci. 24: 1086-1091.

van Soest, P. J., J. B. Robertson, \& B. A. Lewis. 1991. Methods for dietary fiber, neutral detergent fiber, and nonstarch polysaccharides in relation to animal nutrition. J. Dairy Sci. 74: 3583-3597. http://dx.doi.org/10.3168/jds.S00220302(91)78551-2

Sun, Q., F. Gao, Z. Yu, Y. Tao, S. Zhao, \& Y. Cai. 2012. Fermentation quality and chemical composition of shrub silage treated with lactic acid bacteria inoculants and cellulase additives. Anim. Sci. J. 83: 305-309. http://dx.doi. org/10.1111/j.1740-0929.2011.00962.x

Sun, Z. H., S. M. Liu, G. O. Tayo, S. X. Tang, Z. L. Tan, B. Lin, Z. X. He, X. F. Hang, Z. S. Zhou, \& M. Wang. 2009. Effects of cellulase or lactic acid bacteria on silage fermentation and in vitro gas production of several morphological fractions of maize stover. Anim. Feed Sci. Technol. 152: 219-231. http://dx.doi.org/10.1016/j.anifeedsci.2009.04.013

Syahrir, S., K. G. Wiryawan, A. Parakkasi, Winugroho, \& O. N. P. Sari. 2009. Efektivitas daun murbei sebagai pengganti konsentrat dalam sistem rumen in vitro. Med Pet 32: $112-119$.

Tilley, J. M. A. \& R. A. Terry. 1963. A two-stage technique for the in vitro digestion of forage crops. Grass Forage Sci. 18: 104-111. http://dx.doi.org/10.1111/j.1365-2494.1963. tb00335.x

Xing, L., L. Chen, \& L. Han. 2009. The effect of an inoculant and enzymes on fermentation and nutritive value of sorghum straw silages. Bioresour. Technol. 100: 488-491. http:// dx.doi.org/10.1016/j.biortech.2008.06.017 